\title{
EVALUATION AND IMPLEMENTATION OF SURVEILLANCE SYSTEMS DURING THE COVID-19 PANDEMIC AT THE PADANG CLASS II PORT HEALTH OFFICE WORKING AREA OF MINANGKABAU INTERNATIONAL AIRPORT
}

\author{
Yulia Astuti ${ }^{1}$, Aria Gusti ${ }^{2}$, Magdalena ${ }^{3}$ \\ Andalus University ${ }^{1,2}$, Padang Class II Port Health Office ${ }^{3}$ \\ E-mail: yulia.astuti197807@gmail.com', aria.mkes@gmail.com², \\ lena.aliya@gmail.com ${ }^{3}$
}

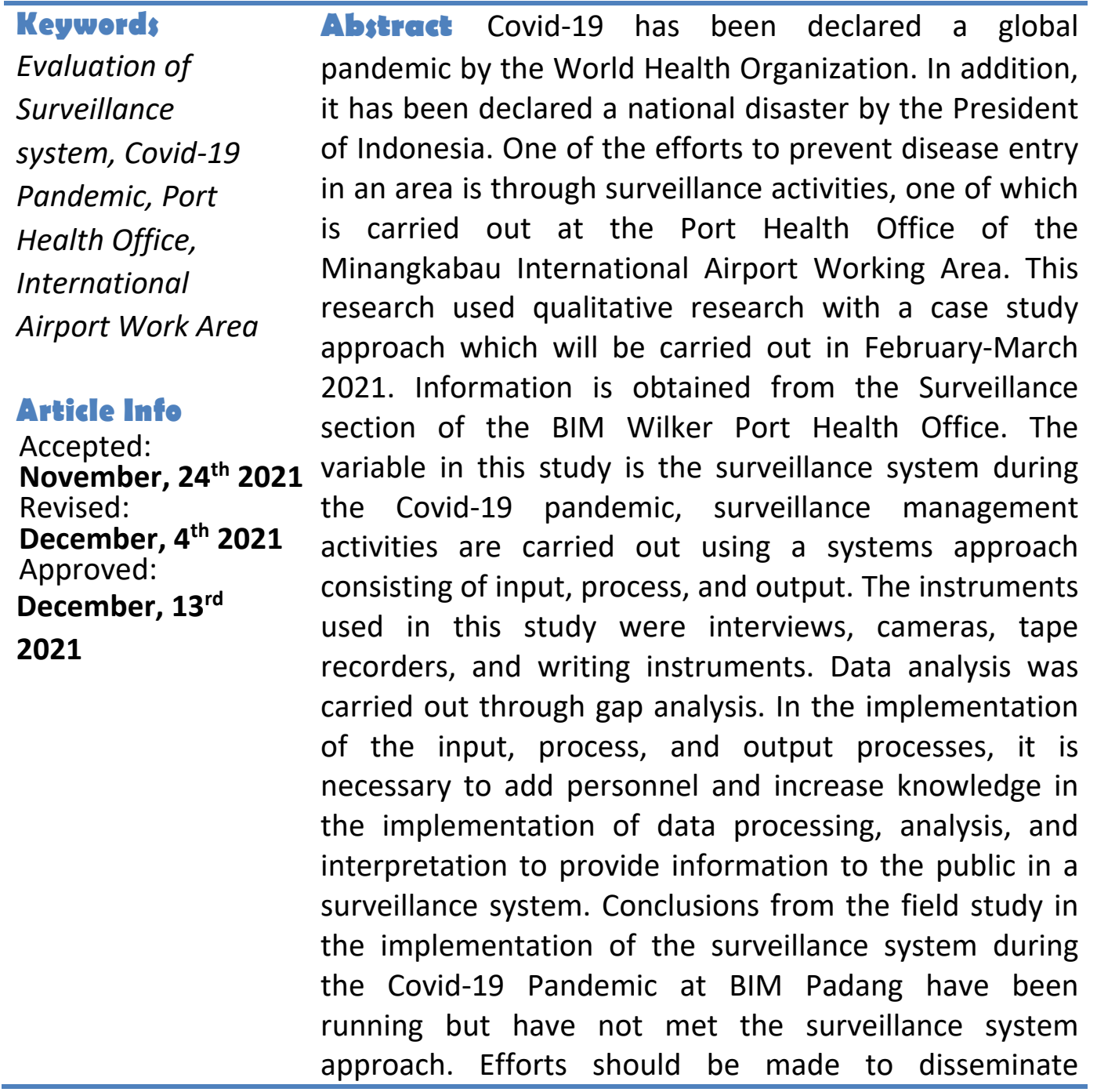


information, socialize and provide human resources and training to improve the capacity of officers.

\section{Introduction}

Minang Kabau International Airport (BIM) is one of the international airports on the island of Sumatra. This airport is one of the air entrances in Indonesia from several other countries such as China, and Malaysia, and other countries. This has led to very strict inspections to control transnational diseases. Disease control in the BIM work area is carried out routinely by the Class II Padang Port Health Office (KKP).

During the Covid-19 pandemic, supervision of the entrance to the departure and arrival of passengers is even stricter to help the government break the chain of the Covid-19 pandemic in Indonesia, especially in West Sumatra Province. The Port Health Office opens a health document inspection counter in the form of validation of Covid-19 test results with rules and conditions applicable at the departure gate and checking e-HAC at the arrival gate for each passenger as one of the surveillance activities for monitoring the health of passengers who will travel or enter BIM Airport (Dabachine, Taheri, Biniz, Bouikhalene, \& Balouki, 2020).

Coronavirus Disease 2019 (COVID-19) is an infectious disease caused by Severe Acute Respiratory Syndrome Coronavirus 2 (SARS-CoV-2) (Acter et al., 2020). SARS-CoV-2 is a new type of coronavirus that has never been previously identified in humans (Ashour, Elkhatib, Rahman, \& Elshabrawy, 2020). There are at least two types of coronavirus that are known to cause diseases that can cause severe symptoms such as Middle East Respiratory Syndrome (MERS) and Severe Acute Respiratory Syndrome (SARS) (Mclntosh \& Perlman, 2015). Common signs and symptoms of COVID-19 infection include symptoms of acute respiratory distress such as fever, cough, and shortness of breath. The average incubation period is 5-6 days with the longest incubation period being 14 days. In severe cases of COVID-19, it can cause pneumonia, acute respiratory syndrome, kidney failure, and even death.

The increase in the number of cases took place quite quickly and spread to various countries in a short time (Onder, Rezza, \& Brusaferro, 2020). As of March 6, 2021, WHO reported 115,653,459 confirmed cases with 2,571,823 deaths worldwide (Case Fatality Rate/CFR 2.2\%) with 222 infected countries and 
187 local transmission countries where CRF data were compared as of July 2020 CFR. 4.6\% has decreased. As of March 6, 2021, the country with the highest number of confirmed cases of Covid-19 was the United States with a total of $28,468,736$ cases, while for the Covid-19 case in ASEAN, Indonesia became the country with the highest confirmed cases of 1,373,836, followed by the Philippines with 587,704 cases and Malaysia. 310,097 cases. The state of Indonesia itself began reporting its first case on March 2, 2020. Cases are increasing and spreading rapidly throughout Indonesia. As of July 9, 2020, the Ministry of Health reported 70,736 confirmed cases of Covid-19 with 3,417 deaths (CFR 4.8\%). As of March 6, 2021, the number of COVID-19 cases in Indonesia that have been examined amounted to 7,420,374 with confirmed Covid-19 cases totaling 1,373,836 cases, $1,189,510$ people recovered, 37,154 deaths with a CRF of $2.7 \%$.

As explained that at KKP Class II Padang where the Quarantine Control and Epidemiological Surveillance Section has the task of preparing planning materials, monitoring, evaluating, compiling reports, and coordinating the implementation of quarantine, disease epidemiological surveillance, potential disease outbreaks, new diseases, and emerging diseases (Agustina, Afidah, \& fadhilah Hasanah, 2021). The data generated in a surveillance system is used to know the picture of the health of a population, take policies that can be applied in the population, both regarding behavior patterns and disease prevention, monitor and evaluate health programs implemented in the community conduct further research related to surveillance data, and identify problems that exist in the population calls.

The scope of surveillance activities itself is quite broad, ranging from early detection of extraordinary events/epidemics, prevention of infectious diseases, to prevention of chronic (non-communicable) diseases that can be carried out within the period of changing behavior patterns to the onset of the disease (Peckham, 2016). Surveillance can be used to collect data on various elements of the disease chain, starting from behavioral risk factors, preventive actions, as well as program evaluation and unit costs (Haddix, Teutsch, \& Corso, 2003). In other words, a surveillance system is needed to get an overview of the disease burden of a community, including the number of cases, incidence, prevalence, case-fatality rate, mortality and morbidity rates, treatment costs, prevention, epidemic potential, and information on the emergence of new diseases. 


\section{Yulia Astuti, Aria Gusti, Magdalena}

Regulation of the Minister of Health Number 45 of 2014 issued by the Ministry of Health of the Republic of Indonesia surveillance management activities is carried out using a systems approach consisting of inputs, processes, and outputs. The input approach can be broken down into 5M (man, money, method, material, market) while the process and output can be adjusted to the needs of management (Hardin \& McCool, 2015).

To produce good output, it is necessary to strengthen in carrying out good input activities as well. Input is an element that is needed in carrying out the program which will later be processed to produce output. According to the concept expressed in management by Harrington Emerson in Phiffner John $F$ and Presthus Robert $\mathrm{V}$, input is composed of $5 \mathrm{M}$ (man, money, method, material, market). Man is a human resource owned by the organization.

In human resource management activities, it is an element that has an important role because management will emerge when every human resource gathers and interacts with each other to achieve the goals determined by the organization. Money and Materials are tools used to achieve organizational goals and have an important role in this. The method is a technique or method used to achieve organizational goals. The parts of the surveillance system approach are as follows:

\section{Input}

1. Man (Human Resources)

Human resources in the field of health called health workers are everyone who dedicates themselves to the health sector and has knowledge and skills through education in the health sector which for certain types requires the authority to carry out health efforts as quoted from Law number 36 of 2014 (Koblinsky et al., 2006). Government the central or local government procures and improves the quality of health workers by providing education and training. From the results of reviewing the guidelines for implementing a health surveillance system, the human resources for implementing an epidemiological surveillance system consist of epidemiologists (S1, S2, S3), trained surveillance staff, health unit managers with an epidemiological orientation, functional ethnology department, sanitarian functional position, laboratory human resources, other human resources related to functional epidemiology.

\section{Money}

In carrying out the surveillance program the funds used can come from the APBD, APBN, Block Grants, and aid funds such as those from NGOs (Rokx, 2009). 
In allocating funds to conduct surveillance programs, each agency has a role in it.

3. Method

There are two methods or approaches that are commonly used in surveillance activities as written in the Minister of Health Regulation number 45. The first is to use the active surveillance method, namely activities carried out by officers directly in the field to record and collect data. Second, passive surveillance, namely surveillance activities carried out by relying on reports from interested parties. In this surveillance activity at the entrance, KKP receives reports from notifications from other affected countries and other regions.

\section{Material}

The facilities and infrastructure used to support an activity or program are elements of the material (Scheckler et al., 1998). Facilities can include moving objects such as ambulances and infrastructure including immovable objects such as isolation rooms, ATK, PPE, surveillance data collection forms, thermal scanners, communication tools, and others.

\section{Market}

The target or market in Covid-19 surveillance activities at the entrance is travelers, namely crew or personnel and passengers, especially those from affected regions or countries, and other areas entering West Sumatra via domestic flights.

\section{Process}

The process carried out is how surveillance activities are carried out to carry out continuous monitoring of all passengers and flight crews before leaving the airport where activities in finding Covid-19 cases at the entrance or arrival include carry out monitoring of travelers; personnel or crew, and passengers, especially those coming from the affected region or country (Khanh et al., 2020). Monitoring is carried out through a thermal scanner or infrared thermometer, monitoring signs and symptoms, or conducting additional health checks. Examination of health documents on travelers. If an indication of high temperature is found from the results of the detection of a thermal scanner or infrared thermometer, the person will be separated for further interviews (Itasari, 2020). If it is found that a traveler has a fever and shows symptoms of pneumonia on the transportation equipment based on the report of the transportation equipment personnel, the KKP officer will check the transportation equipment using standard PPE. The treatment given to travelers is by the conditions and criteria of the case, and the procedures for handling cases (Makurumidze, 2020). Take action according to SOP for goods and transportation equipment. 


\section{Yulia Astuti, Aria Gusti, Magdalena}

\section{Output}

The results of surveillance activities for each activity have their results. However, in general, the results of epidemiological surveillance activities produce information that can be disseminated to the wider community.

\section{Research Method}

The method used is taken from the Regulation of the Minister of Health Number 45 of 2014 issued by the Ministry of Health of the Republic of Indonesia where surveillance management activities are carried out using a systems approach consisting of input, process, and output. The input approach can be broken down into 5M (man, money, method, material, market) while the process and output are expected to produce information that is disseminated to the public and can be used as a reference in making a policy and as a guide in planning a program in the future.

\section{Result and Discussion}

Epidemiological surveillance at KKP Class II Padang BIM Working Area is carried out through input, process, and output stages. The description of these stages is as follows:

1. Inputs

a. Man (power)

The surveillance staff at Class II Padang Port Health Office in the BIM Working Area consists of 10 people who are in the Quarantine Control and Epidemiological Surveillance (PKSE) section consisting of State Civil Apparatus (ASN) and Non-ASN with educational backgrounds of D3 Health, S1 Public Health, and S2 Health.

In carrying out surveillance activities at the airport, they are also assisted by officers from the Environmental Risk Control (PRL) section and the Health Efforts and Cross-regional (UKLW) section so that the number of personnel at the Class II Padang Port Health Office in the BIM Work Area is 22 people who are in the implementation of this activity. Surveillance in 2020 at Wilker BIM consists of two shifts, morning and evening, but in February 2021, surveillance work activities at Wilker BIM will be divided into three shifts, morning, afternoon, and night. 
Table 1. Availability of Human Resources in Class II KKP

\begin{tabular}{llllll}
\hline \multirow{2}{*}{ Power Type } & & $\begin{array}{l}\text { Amount } \\
\text { available }\end{array}$ & Standard & \multicolumn{2}{c}{ Adequacy } \\
\cline { 5 - 6 } & & 1 & 2 & & V \\
\hline 1 & $\begin{array}{l}\text { Epidemiologist } \\
\text { Expert (S2) }\end{array}$ & & & & No \\
2 & $\begin{array}{l}\text { Epidemiologist } \\
\text { Expert (S1) }\end{array}$ & 7 & 4 & $\mathrm{~V}$ & $\mathrm{~V}$ \\
3 & Skilled Epidemiology & 1 & 4 & - & $\mathrm{V}$ \\
4 & General Doctors & 6 & 1 & $\mathrm{~V}$ & - \\
\hline
\end{tabular}

b. Money

Available in the form of an existing budget in the KKP originating from the State Budget of the Ministry of Health, Directorate General of P2P as stated in the Padang Class II KKP activity budget plan for 2020-2024 with measurable targets and targets so that surveillance activities at Wilker BIM are expected to be carried out properly and as expected in prevention and control of Covid-19. The total budget and achievements of the 2020 PKSE Section Budget are as follows:

Table 2. PKSE Section Budget Achievement in 2020

\begin{tabular}{lllll}
\hline & \multicolumn{3}{c}{ THE FINANCIAL YEAR 2020 } \\
\cline { 2 - 5 } $\begin{array}{l}\text { PROGRAMS/ACTI } \\
\text { VITIES/ OUTPUT }\end{array}$ & INDICATOR & \multicolumn{3}{c}{ BUDGET } \\
\cline { 2 - 5 } & TARGET & ACHIEVEMENT & ALLOCATION & $\begin{array}{l}\text { REALIZATI } \\
\text { ON }\end{array}$ \\
\hline $\begin{array}{l}\text { Health } \\
\text { Quarantine }\end{array}$ & 719 Service & 719 Service & $170,340,000$ & $\begin{array}{l}156,314,9 \\
\text { Service }\end{array}$ \\
\hline & & & & 60 \\
\hline Total & & 719 Service & $170,340,000$ & $\begin{array}{l}156,314,9 \\
60\end{array}$ \\
\hline
\end{tabular}

c. Method

Surveillance methods are carried out actively and passively. The implementation of surveillance at the Wilker Airport KKP actively observes passengers who want to depart by checking the results of the Rapid Test which are still valid for 


\section{Yulia Astuti, Aria Gusti, Magdalena}

departure according to the applicable provisions where the results of the Covid19 test are negative, where if an antigen test is carried out, the validity period of the test is $2 \times 24$ hours from the results a negative test comes out, but if the test is PCR, the negative test result is valid for $3 \times 24$ hours. Furthermore, on arrival, an e-HAC scan check is carried out as an effort to prevent Covid-19 for all passengers where one e-HAC application can be used for ten passengers. Furthermore, at Arrival, passenger supervision is also carried out with a Thermo scanner to check the body temperature of passengers on arrival.

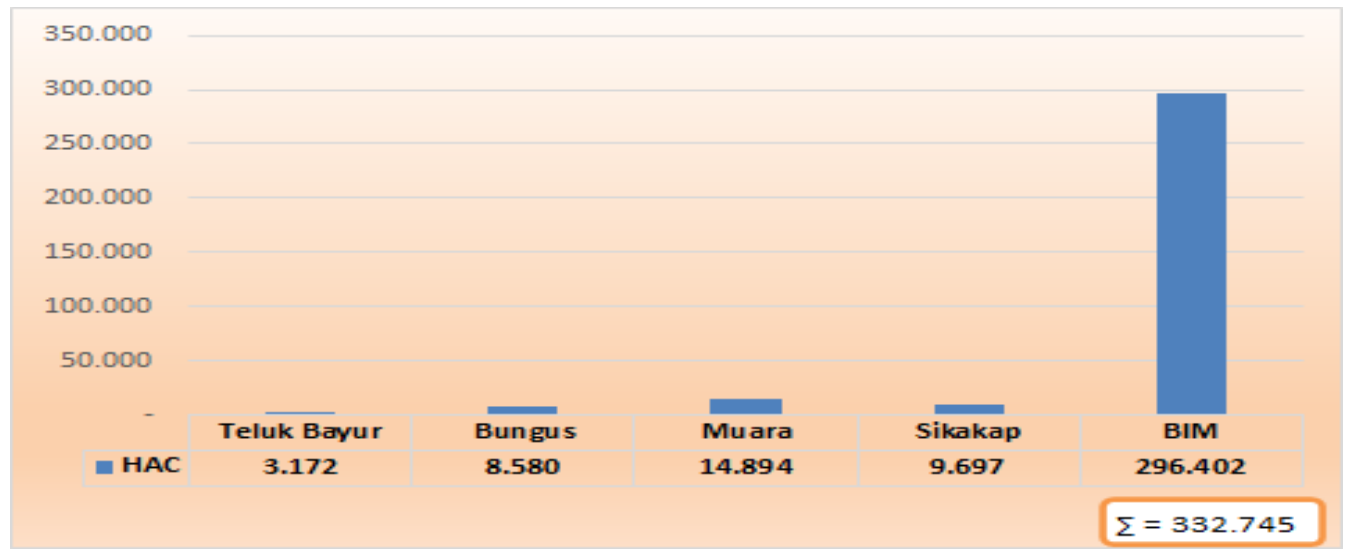

Picture 1. HAC Data Collection Distribution 2020

\section{d. Material}

In the form of facilities and infrastructure used to support an activity. Facilities can include moving objects such as ambulances and infrastructure including immovable objects such as isolation rooms, ATK, PPE, surveillance data collection forms, thermal scanners, communication tools, and others in the form of equipment used in the implementation of surveillance activities at the airport. complete, it is just that there are some tools whose usability is still not optimal, such as a thermal scanner on arrival as an automatic tool to check body temperature. 


\begin{tabular}{|c|c|c|c|c|c|c|c|c|c|c|}
\hline \multirow[b]{2}{*}{ No } & \multicolumn{2}{|c|}{ Uraian BMN } & \multirow[b]{2}{*}{ Merk / Type } & \multirow[b]{2}{*}{ Jumlah } & \multirow[b]{2}{*}{ Lokasi } & \multirow{2}{*}{$\begin{array}{c}\text { Penanggung } \\
\text { jawab }\end{array}$} & \multicolumn{3}{|c|}{ Kondisi } & \multirow[b]{2}{*}{ Ket } \\
\hline & Kd Barang & Nama Barang & & & & & Baik & $\begin{array}{r}\text { Rusak } \\
\text { Ringan }\end{array}$ & \begin{tabular}{|l|} 
Rusak \\
Berat
\end{tabular} & \\
\hline 1 & 3.09.04.03.004.3.2015 & GPSMAP 64S & GARMIN & 1 & Teluk Bayur & Seksi PKSE & $\mathrm{V}$ & & & \\
\hline 2 & 3.09.04.03.004.001.2013 & eTrex 10 & GARMIN & 1 & Teluk Bayur & Seksi PKSE & V & & & \\
\hline 3 & 3.09.04.05.012.3.2020 & Barcode ICV & & 1 & Teluk Bayur & Seksi PKSE & $\mathrm{V}$ & & & \\
\hline 4 & 3.09.04.05.012.4.2020 & Barcode ICV & & 1 & Teluk Bayur & Seksi PKSE & $\mathrm{V}$ & & & \\
\hline 5 & 3.09.04.05.012.5.2020 & Barcode ICV & & 1 & Teluk Bayur & Seksi PKSE & V & & & \\
\hline 6 & 3.09.04.05.012.6.2020 & Barcode ICV & & 1 & Teluk Bayur & Seksi PKSE & V & & & \\
\hline 7 & 3.10.01.02.009.12018 & Tablet & SAMSUNG & 1 & Wilker BIM & Seksi PKSE & V & & & \\
\hline 8 & 3.10.01.02.002.2015 & Laptop & ASUS & 1 & Wilker BIM & Seksi PKSE & V & & & \\
\hline 9 & 3.09.04.03.004.2015 & GPSMAP & GARMIN & 1 & Wilker BIM & Seksi PKSE & $\mathrm{V}$ & & & \\
\hline 10 & 3.09.04.09.078.1.2018 & Thermal Scanner & DELL & 1 & Wilker BIM & Seksi PKSE & $\mathrm{V}$ & & & \\
\hline 11 & 3.10 .10 .02 .01 .009 .3 .2018 & $\begin{array}{l}\text { Printer Thermal } \\
\text { Scanner }\end{array}$ & & 1 & Wilker BIM & Seksi PKSE & v & & & \\
\hline 12 & 3.09.04.09.078.2.2019 & Thermal Scanner & APC & 2 & Wilker BIM & Seksi PKSE & & V & & \begin{tabular}{|l|}
1 camera \\
tidak bisa di \\
operasikan
\end{tabular} \\
\hline 13 & 3.09.04.05.012.1.2019 & Barcode ICV & & 1 & Wilker BIM & Seksi PKSE & $\mathrm{v}$ & & & \\
\hline 14 & 3.09 .04 .05 .012 .2 .2019 & Barcode ICV & & 1 & Wilker BIM & Seksi PKSE & $\mathrm{V}$ & & & \\
\hline
\end{tabular}

Picture 2. Quarantine \& SE. Control Section Equipment

e. Market

As a marker, all travelers, both passengers, and all crew members are the object of surveillance at the Wilker Padang KKP. During the pandemic period, there are no flights from abroad so only domestic flights so that in monitoring for passengers only passengers from within the territory of Indonesia.

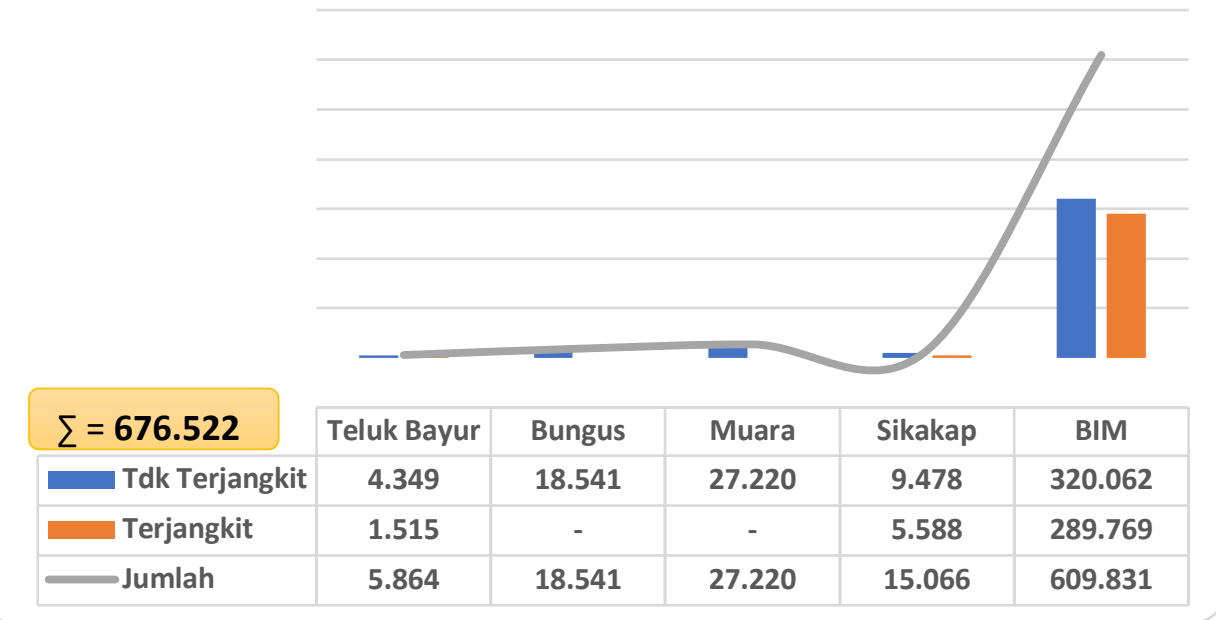

Picture 3. Distribution of Domestic Passenger Arrivals in 2020

The number of domestic passenger arrivals at the port/airport in the Padang Class II KKP Work Area in 2020 Wilker BIM was 609,831 people (90.14\%) and the rest were at other wilkers so that the highest number of passenger arrivals was at BIM. When compared to the arrival of domestic passengers in 2019, which was $1,352,471$ people, there was a fairly large decrease of 675,949 people (49.98\%). 
2. Process

a. Data collection

Data collection is carried out by surveillance officers to aircraft passengers by direct observation and supervision of the arrival of domestic flight passengers because since Covid-19 there are no longer international flights at KKP wilker BIM. Data collection is carried out by officers using an inspection form that is filled in by the supervising officer based on interviews with passengers or carried out by each passenger through the eHAC Application. For e-HAC data itself, every month it is always different from the result of the number of passengers that should be. Where the number of Passenger data should be the same as the number of eHAC, so there is always a lack of passenger eHAC data.

b. Data processing.

Data that has entered the system will be sent to the Ministry of Health and will be processed directly in the system. However, the data processing carried out by the KKP itself has not been processed properly so that it cannot represent a good surveillance system.

c. Analysis and interpretation

the analysis has also not been carried out properly because the data is not processed properly. This is due to the absence of special and trained personnel in processing and analyzing surveillance data.

3. Output

The output of epidemiological surveillance activities produces information that can be disseminated to the general public that can be easily understood and can also be used as a reference in the success of a program as well as a reference by policy makers in planning further programs.

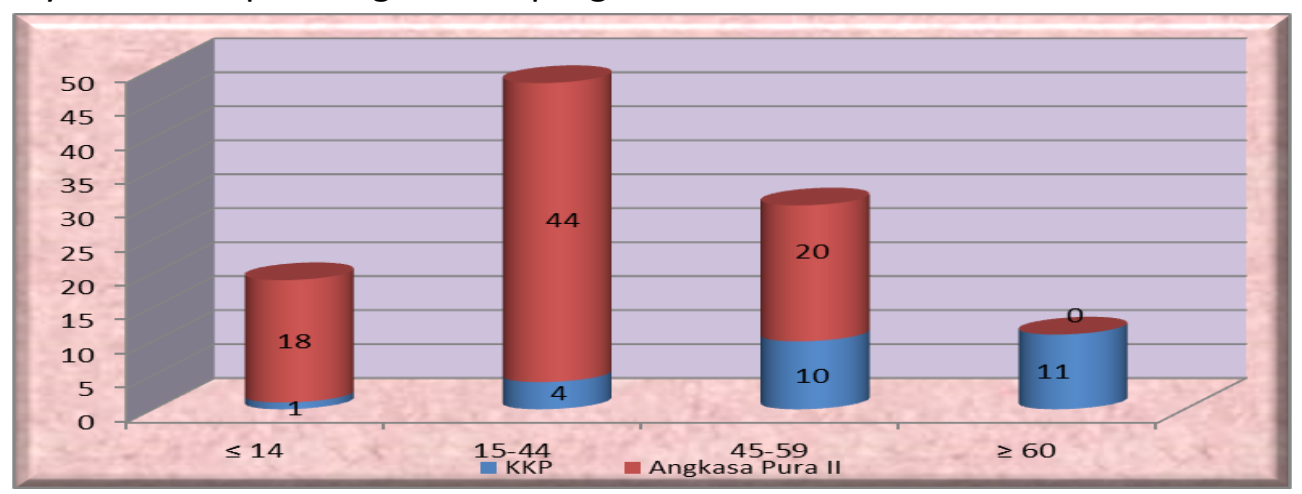

Picture 4. BIM Working Area Polyclinic VisitBy Age Group January 2021 Source: Padang MPA Class II Data 
From the results obtained during field studies at KKP Padang, the BIM work area, it can be described for the personnel themselves, according to the standard for routine epidemiological surveillance activities, but if it is based on the KMK standard No. 1116 of 2003 as table 1 (one) where personnel/resources are still a problem where there are personnel who have met the standards and some have not. KKP Padang has 4 (four) wilkers, it is necessary to add surveillance personnel as well as at the Padang BIM Wilker so that all surveillance activities can be carried out because based on the results of interviews since the Covid-19 pandemic, the BIM Wilker KKP officers are more focused on validating Covid 19 test results on departure and e-HAC scans at the arrival of passengers so that other surveillance activities at BIM are disrupted. Furthermore, the addition of work shifts from two to three consisting of morning, afternoon, and evening shifts will certainly also affect the implementation of surveillance activities.

To solve the problem of manpower, it is necessary to increase the number of personnel, either by adding personnel with a contract system and also by proposing the acceptance of civil servants at KKP Padang. In addition, surveillance personnel needs training in increasing the ability to carry out a surveillance activity so that the expected results for the success of the surveillance system can be carried out so those surveillance activities can assist in the implementation of control programs and the implementation of vigilance, preparedness for the possibility of outbreaks in the work area. BIM KKP Class II Padang.

Availability of the existing budget in the KKP originating from the State Budget of the Ministry of Health, Directorate General of P2P as stated in the Padang Class II KKP activity budget plan for 2020-2024 with measurable targets and targets so that it is hoped that surveillance activities at Wilker BIM can be carried out properly and as expected in prevention and control of Covid-19. And for the budget available to carry out surveillance programs and other programs at the Padang KKP there is an increase from 2020 to 2021. The budget is very supportive in carrying out surveillance activities and other activities. The RAK has also been provided to increase the capacity of the apparatus in adding insight and skills to carry out surveillance activities. 


\section{Yulia Astuti, Aria Gusti, Magdalena}

Surveillance methods in the KKP are carried out actively and passively, manually and electronically (by utilizing an android smartphone). On departure with validation of the Covid-19 test results with applicable terms and conditions, where the validity period of negative antigen and PCR test results is $2 \times 24$ hours for negative test results for antigens, and $3 \times 24$ hours for negative PCR test results, however online is sometimes constrained by a signal so sometimes it takes longer.

In the form of facilities and infrastructure used to support an activity. Facilities can include moving objects such as ambulances and infrastructure including immovable objects such as isolation rooms, ATK, PPE, surveillance data collection forms, thermal scanners, communication tools, and others in the form of equipment used in the implementation of surveillance activities at the airport. complete, it's just that there are some tools whose usability is still not optimal, such as a thermal scanner on arrival as an automatic tool to check body temperature.

As a marker, all travelers, both passengers, and all crew members are the object of surveillance at the Wilker Padang KKP. During the pandemic period, there are no flights from abroad so only domestic flights so that in the monitoring for passengers only passengers from within the territory of Indonesia. The target for BIM surveillance activities on passengers is only at the airport after they leave the airport, it is no longer the responsibility of the BIM wilker surveillance officer so that the monitoring is only limited to the airport. If there is a positive case from a new traveler, there will be a notification report to the West Sumatra Provincial Health Office.

Data collection is carried out by surveillance officers to aircraft passengers by direct observation and supervision of the arrival of domestic flight passengers because since Covid-19 there are no longer international flights at KKP wilker BIM. Data collection is carried out by officers using an inspection form that is filled in by the supervising officer based on interviews with passengers or carried out by each passenger through the eHAC Application. For e-HAC data itself, every month it is always different from the result of the number of passengers that should be. Where the number of Passenger data should be the same as the number of eHAC, so there is always a lack of passenger eHAC data. 
Data is an important variable in epidemiological surveillance activities, completeness, and accuracy of data are very important in processing data. Accurate data will produce a good outcome in evaluating a surveillance activity. Data that has entered the system will be sent to the Ministry of Health and will be processed directly in the system. However, the data processing carried out by the KKP itself has not been processed properly so that it cannot represent a good surveillance system. This is due to officers who have multiple tasks so that they cannot complete report data on time, and also the expertise of surveillance officers needs to be honed again in processing surveillance data so that it becomes a report that can be needed and reliable in taking every appropriate step.

The analysis has also not been carried out properly because the data is not processed properly. This is because there are no special and trained personnel in processing and analyzing surveillance data so that all existing data is the responsibility of only one person where the surveillance officer only needs to submit reports every day.

Epidemiological surveillance activities produce information that can be disseminated to the general public that can be easily understood and can also be used as a reference in the success of a program as well as a reference by policymakers in planning further programs. For Covid-19 epidemiological surveillance, data that has been received by the TC-19, All Record system can be accessed through the One Health Data Dashboard application. Dissemination can be by issuing or making a Surveillance Bulletin which contains information to the public about the activities carried out by the KKP wilker BIM at the air entrance for monitoring diseases entering the Indonesian Territory.

Evaluation of surveillance activities during departure validation and e-HAC checks for passenger arrivals at the Class II Padang Port Health Office, BIM Work Area, is important because Covid-free documents from hospitals and laboratories are very vulnerable to being faked as well as upon arrival in filling out e-mails. HAC can also be a possibility that the data is not filled incorrectly. For e-HAC scan data itself, every month there is always the same number of passengers reported by the airport authority, even though the number of e-HAC scans should be the same as the number of passengers reported. This means that there is a system weakness in conducting surveillance of passengers, so it is necessary to pay attention to all parties to find a solution so that the number of passengers reported is the same as the number of e-HAC scans. 


\section{Conclusion}

In all surveillance systems that are carried out in the process of input, process, and output, it is very important to follow up on officers who have dual duties, due to inadequate personnel, furthermore, there are still some surveillance officers who are still in general functional positions of Epidemiology, and officers who have not mastered the processing system in processing, analyzing and interpreting data in reporting, being slow in completing monthly reports, and annual reports, so that it will be late in disseminating information and in taking a policy in a surveillance system so that additional personnel and capacity building of officers are needed through training/training in processing, analyzing and interpreting surveillance data.

\section{References}

Acter, Thamina, Uddin, Nizam, Das, Jagotamoy, Akhter, Afroza, Choudhury, Tasrina Rabia, \& Kim, Sunghwan. (2020). Evolution of severe acute respiratory syndrome coronavirus 2 (SARS-CoV-2) as coronavirus disease 2019 (COVID-19) pandemic: A global health emergency. Science of the Total Environment, 730, 138996.

Agustina, Dewi, Afidah, Huwaina, \& fadhilah Hasanah, Nur. (2021). Performance Analysis of Covid-19 Epidemiology Surveillance at the Class 1 Port Health Office Batam in the Batam Center International Ferry Port Work Area. European Journal of Molecular \& Clinical Medicine, 8(03), 2021.

Ashour, Hossam M., Elkhatib, Walid F., Rahman, Md, \& Elshabrawy, Hatem A. (2020). Insights into the recent 2019 novel coronavirus (SARS-CoV-2) in light of past human coronavirus outbreaks. Pathogens, $9(3), 186$.

Dabachine, Yassine, Taheri, Hamza, Biniz, Mohamed, Bouikhalene, Belaid, \& Balouki, Abdessamad. (2020). Strategic design of precautionary measures for airport passengers in times of global health crisis Covid 19: Parametric modelling and processing algorithms. Journal of Air Transport Management, 89, 101917.

Haddix, Anne C., Teutsch, Steven M., \& Corso, Phaedra S. (2003). Prevention effectiveness: a guide to decision analysis and economic evaluation. Oxford University Press.

Hardin, Brad, \& McCool, Dave. (2015). BIM and construction management: proven tools, methods, and workflows. John Wiley \& Sons.

Itasari, Endah Rantau. (2020). COVID-19 HANDLING IN THE BORDER AREAS OF INDONESIA. Jurnal Pendidikan Kewarganegaraan Undiksha, 8(3), 4250.

Evaluation and Implementation of Surveillance Systems during the Covid-19 Pandemic at the Padang Class II Port Health Office Working Area of Minangkabau 
Khanh, Nguyen Cong, Thai, Pham Quang, Quach, Ha Linh, Thi, Ngoc Anh Hoang, Dinh, Phung Cong, Duong, Tran Nhu, Mai, Le Thi Quynh, Nghia, Ngu Duy, Tu, Tran Anh, \& Quang, La Ngoc. (2020). Transmission of SARSCoV 2 during long-haul flight. Emerging Infectious Diseases, 26(11), 2617.

Koblinsky, Marge, Matthews, Zoë, Hussein, Julia, Mavalankar, Dileep, Mridha, Malay K., Anwar, Iqbal, Achadi, Endang, Adjei, Sam, Padmanabhan, P., \& van Lerberghe, Wim. (2006). Going to scale with professional skilled care. The Lancet, 368(9544), 1377-1386.

Makurumidze, Richard. (2020). Coronavirus-19 disease (COVID-19): A case series of early suspected cases reported and the implications towards the response to the pandemic in Zimbabwe. Journal of Microbiology, Immunology and Infection, 53(3), 493-498.

Mclntosh, Kenneth, \& Perlman, Stanley. (2015). Coronaviruses, including severe acute respiratory syndrome (SARS) and Middle East respiratory syndrome (MERS). Mandell, Douglas, and Bennett's Principles and Practice of Infectious Diseases, 1928.

Onder, Graziano, Rezza, Giovanni, \& Brusaferro, Silvio. (2020). Case-fatality rate and characteristics of patients dying in relation to COVID-19 in Italy. Jama, 323(18), 1775-1776.

Peckham, Robert. (2016). Epidemics in modern Asia (Vol. 15). Cambridge University Press.

Rokx, Claudia. (2009). Health financing in Indonesia: a reform road map. World bank publications.

Scheckler, William E., Brimhall, Dennis, Buck, Alfred S., Farr, Barry M., Friedman, Candace, Garibaldi, Richard A., Gross, Peter A., Harris, Jo Ann, Hierholzer, Walter J., \& Martone, William J. (1998). Requirements for infrastructure and essential activities of infection control and epidemiology in hospitals: a consensus panel report. Infection Control \& Hospital Epidemiology, 19(2), 114-124.

\section{Copyright holder :}

Yulia Astuti, Aria Gusti, Magdalena (2021)

First publication right :

Devotion : Journal of Research and Community Service

This article is licensed under:

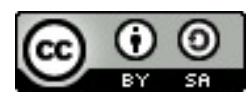

